\title{
Case Report: Histiocytic Necrotizing Lymphadenitis (Kikuchi-Fujimoto Disease) Concurrent With Aseptic Meningitis
}

\author{
Yanna Song, Shan Liu, Lei Song, Huaqiu Chen, Miaoshui Bai, Jinhua Yan, Tianfei Luo, \\ Kangding Liu, Li Sun and Yang Zhao*
}

Department of Neurology and Neuroscience Center, The First Hospital of Jilin University, Changchun, China

Kikuchi-Fujimoto disease (KFD), also known as histiocytic necrotizing lymphadenitis, is a rare, benign, self-limiting disease characterized by local lymphadenopathy. Central nervous system involvement in KFD is extremely rare and remains a diagnostic challenge. Only 41 cases of aseptic meningitis associated with KFD have been reported worldwide, with just four cases (including our case) of KFD with meningitis as the first symptom. We report a case of KFD accompanied by aseptic meningitis with severely high intracranial pressure $\left(400 \mathrm{mmH}_{2} \mathrm{O}\right)$, increased white blood cell count $\left(56 \times 10^{6} / \mathrm{L}\right)$, and moderately elevated protein level $(0.52 \mathrm{~g} / \mathrm{L})$. This case is unique in the delayed appearance of lymphadenopathy. After 1 month of treatment with steroids, fever, headache, and lymphadenopathy gradually disappeared, and the result of cerebrospinal fluid examination gradually became normal. In conclusion, based on our case findings and our literature review on KFD with aseptic meningitis, a diagnosis of KFD should be considered when delayed appearance of lymphadenopathy is observed in patients with aseptic meningitis.

drzhaoyang123456@1 Yang Zhao yangzhao@jluedu.ch

Keywords: aseptic meningitis, Kikuchi-Fujimoto disease, histiocytic necrotizing lymphadenitis, case report, lymphadenopathy

\section{INTRODUCTION}

Histiocytic necrotic lymphadenitis (HNL), first described by Japanese pathologists Kikuchi and Fujimoto et al. $(1,2)$ and also called Kikuchi-Fujimoto disease (KFD), is a rare local lymphadenopathy with a benign course and with clinical manifestations including fever, lymphadenopathy, rash, hepatosplenomegaly, central nervous system (CNS) symptoms, and hemophilic cell syndrome. KFD involves a variety of tissues and organs as well as the CNS, causing damage to the meninges, brain parenchyma, and peripheral nerves and even presenting neurological symptoms as prominent clinical manifestations or first symptoms. To date, most reports are based on the pathological features of KFD, and clinical reports of neurological damage as the first symptom are rare. Herein we discuss the case of a patient diagnosed with aseptic meningitis as the first clinical feature and who was ultimately diagnosed with KFD. Furthermore, we retrieved information on all patients diagnosed with KFD accompanied by aseptic meningitis from PubMed and conducted a comprehensive review of the etiology, clinical manifestations, auxiliary examination, diagnosis, prognosis, and treatment of this disease. 


\section{CASE DESCRIPTION}

A 20-year-old Chinese man with a complaint of headache and fever for 5 days was admitted to our hospital. He had no specific medical history except for Ebstein anomaly corrective surgery at the age of 15 years. His family history was unremarkable. The temperature on admission was $38.1^{\circ} \mathrm{C}$. Meningeal irritation signs, including neck stiffness and Kernig's sign, were absent. On admission, the laboratory test results revealed normal complete blood count, coagulation tests, erythrocyte sedimentation rate, procalcitonin, C-reactive protein, anti-streptolysin $\mathrm{O}$, rheumatoid factor, tumor markers, antinuclear antibody $(\mathrm{Ab})$, anti-dsDNA Ab, and anti-cardiolipin Ab. Serum antibodies against Epstein-Barr virus (EBV) showed a pattern of previous infection. Cranial computed tomography (CT) and CT venography were unremarkable. The initial intracranial pressure (ICP) measured was $220 \mathrm{mmH}_{2} \mathrm{O}$ (normal range, $80-180 \mathrm{mmH}_{2} \mathrm{O}$ ) (Table $\mathbf{1}$, day 6 after symptom onset). Biochemical detection of cerebrospinal fluid (CSF) including protein, glucose, chlorine, and white blood cells showed that these were all within normal ranges. As meningitis was suspected, he was administered intravenously (IV) with acyclovir. However, the headache was not relieved after antiviral treatment. A second lumbar puncture (Table 1, day 11) revealed clear CSF with an opening pressure of $300 \mathrm{mmH}_{2} \mathrm{O}$. The CSF biochemical results were within the normal range. CSF cultures for bacteria, acidfast bacilli, and fungi were also negative. Results of polymerase chain reaction (PCR) for herpes simplex virus, cytomegalovirus, human herpesvirus, EBV, and herpes zoster virus were normal. Meanwhile, he was administered IV with acyclovir, mannitol, and other symptomatic treatments.

On the 7th day after admission, the patient developed a severe headache accompanied by a rash all over the body (Figure 1). Neck stiffness and Kernig's sign were positive. Fever was essentially unaffected. Routine laboratory tests were normal as before. A third lumbar puncture examination (Table 1, day 17) showed a $400-\mathrm{mmH}_{2} \mathrm{O}$-high cranial pressure with elevated

Abbreviations: HNL, histiocytic necrotic lymphadenitis; KFD, Kikuchi-Fujimoto disease; EBV, Epstein-Barr virus; CSF, cerebrospinal fluid; SLE, systemic lupus erythematosus; PCR, polymerase chain reaction; $\mathrm{CNS}$, central nervous system; $\mathrm{Ab}$, antibody; CT, computed tomography; IV, intravenous; ICP, intracranial pressure. protein $(0.52 \mathrm{~g} / \mathrm{L}$; normal range, $0.15-0.45 \mathrm{~g} / \mathrm{L})$ and white blood cell count $\left(56 \times 10^{6} / \mathrm{L}\right.$; normal range, $\left.0-8 \times 10^{6} / \mathrm{L}\right)$, among which monocytes represented about $92 \%$, while glucose and chlorine levels were normal. The repeated CSF culture was sterile, and the PCR for viral agents was negative. At this point, mannitol was continued, and the dosage was increased to treat elevated ICP.

On the 14th day after admission, several discrete, tender, and rubbery lymph nodes $10-20 \mathrm{~mm}$ in size were present on both sides at the posterior neck. Ultrasonography of the neck revealed multiple swollen bilateral cervical lymph nodes, some as large as $21 \times 8.5 \mathrm{~mm}$. A cervical lymph node biopsy demonstrated numerous lympho-histiocytic cells and karyorrhectic debris

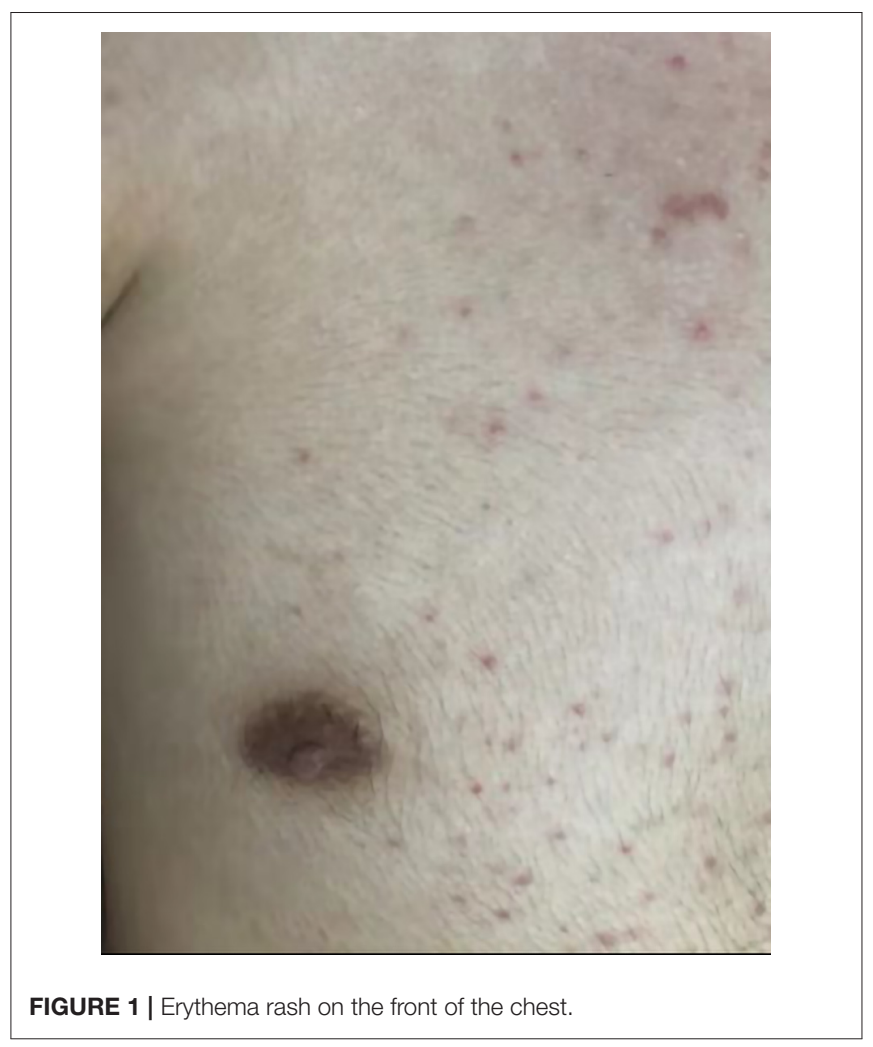

TABLE 1 | Cerebrospinal fluid examination.

\begin{tabular}{|c|c|c|c|c|c|c|}
\hline $\begin{array}{l}\text { Days } \\
\text { after symptom onset }\end{array}$ & $\begin{array}{l}\text { Intracranial pressure } \\
\left(80 \sim 180 \mathrm{mmH}_{2} \mathrm{O}\right)\end{array}$ & $\begin{array}{c}\text { Protein } \\
(0.15 \sim 0.45 \mathrm{~g} / \mathrm{L})\end{array}$ & $\begin{array}{c}\text { Glucose (2.3 4.1 } \\
\mathrm{mmol} / \mathrm{L})\end{array}$ & $\begin{array}{c}\text { Chloride } \\
(119 \sim 129 \mathrm{mmol} / \mathrm{L})\end{array}$ & $\begin{array}{l}\text { White blood cell } \\
\text { count }\left(0 \sim 8 \times 10^{6} / \mathrm{L}\right)\end{array}$ & $\begin{array}{l}\text { Leukocyte classification } \\
\text { (\%) }\end{array}$ \\
\hline Day 6 & 220 & 0.36 & 3.7 & 120 & 6 & $\begin{array}{l}\text { Coenocyte } 16 \\
\text { Monocytes } 83\end{array}$ \\
\hline Day 11 & 300 & 0.32 & 3.7 & 128.7 & 3 & - \\
\hline Day 17 & 400 & 0.52 & 3.5 & 127.4 & 56 & $\begin{array}{l}\text { Coenocyte } 8 \\
\text { Monocytes } 92\end{array}$ \\
\hline Day 23 & 260 & 0.32 & 3.1 & 128.7 & 32 & $\begin{array}{l}\text { Coenocyte } 99 \\
\text { Monocytes } 1\end{array}$ \\
\hline Day 52 & 220 & 0.31 & 3.2 & 124.9 & 10 & $\begin{array}{l}\text { Coenocyte } 10 \\
\text { Monocytes } 90\end{array}$ \\
\hline
\end{tabular}




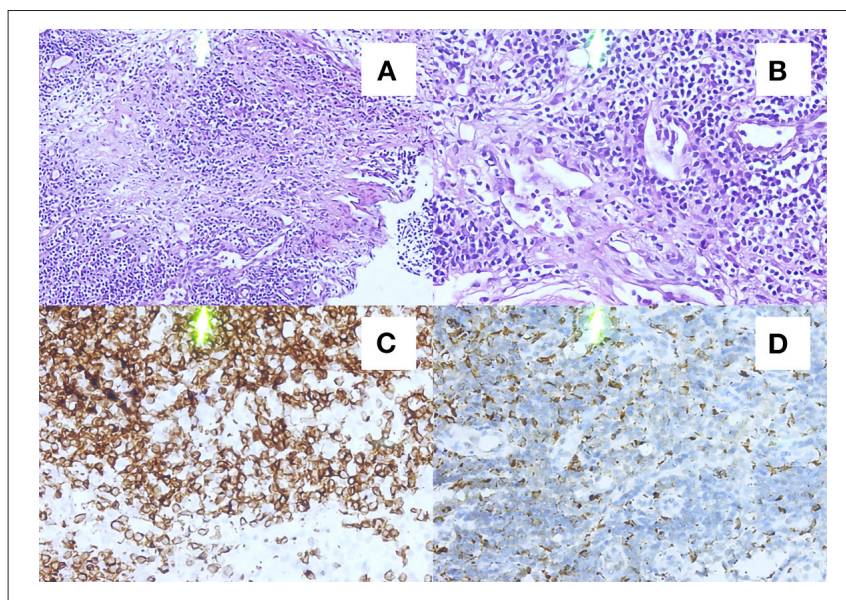

FIGURE 2 | Histopathological and immunohistochemical findings of cervical lymph nodes. Hematoxylin-eosin staining showing hyperplasia, histiocytosis, and a few nuclear fragments in the left cervical lymph node sections. (A,B) Immunohistochemical staining showing $\mathrm{CD}^{+}$(C) and $\mathrm{CD}^{+} 8^{+}$(D) expression in the left side cervical lymph node sections.

without neutrophils, suggesting KFD. Immunohistochemical staining showed $\mathrm{CD}^{+} 8^{+}$histocytes and $\mathrm{CD} 3^{+} \mathrm{T}$ cells, further indicating KFD (Figure 2). The absence of Reed-Sternberg cells, hematoxylin bodies, and neutrophils excluded the diagnosis of Hodgkin's disease and systemic lupus erythematosus (SLE). A fourth lumbar puncture (Table 1, day 23) revealed a decreased ICP of $260 \mathrm{mmH}_{2} \mathrm{O}$ and WBC of $32 \times 10^{6} / \mathrm{L}$ (monocytes $99 \%$ ), while the other biochemical tests were normal. Based on the clinical manifestations and the CSF and cervical lymph node biopsy findings, the patient was diagnosed with KFD with aseptic meningitis. The treatment was adjusted to oral methylprednisolone administration (40 mg per day), which was tapered to $8 \mathrm{mg}$ per day. During this period, the patient's clinical symptoms and CSF parameters (Table 1, day 52) gradually resolved. The patient was satisfied with the treatment outcome and had good compliance with follow-up. After 10 months of follow-up, no symptoms or signs of meningitis relapse or evolution into other autoimmune diseases were detected.

\section{DISCUSSION}

Herein we report an unusual case of KFD concurrent with aseptic meningitis. The patient presented with persistent fever, headache, skin rash, cervical lymphadenopathy, and positive meningeal irritation signs such as neck stiffness and Kernig's sign. The CSF culture was sterile, and lymph node biopsy revealed typical karyorrhectic debris and $\mathrm{CD}^{+} 8^{+}$histiocytes, which confirmed the diagnosis of KFD concurrent with aseptic meningitis. The patient's symptoms improved after treatment with steroids. In addition, the patient presented with less commonly reported symptoms, including initial aseptic meningitis and delayed lymphadenopathy, which further interfered with an early diagnosis of the disease. A literature review on the topic of KFD and aseptic meningitis was performed in PubMed using the following terms: "Kikuchi-Fujimoto disease aseptic meningitis,"
"Kikuchi disease aseptic meningitis," "histiocytic necrotizing lymphadenitis aseptic meningitis," "Kikuchi-Fujimoto disease central nervous system," "Kikuchi disease central nervous system," and "histiocytic necrotizing lymphadenitis central nervous system." We identified 41 cases (including the present case) to include in this review. Table 2 summarizes the epidemiological and clinical characteristics, laboratory features, brain MRI, prognosis, treatment, and outcomes of all cases.

$\mathrm{HNL} / \mathrm{KFD}$ is a rare form of lymphadenitis of unclear etiology. Most scholars believe that the pathogenesis of KFD is related to viral infection and the auto-immune response is mediated by viral infection (3). In statistical terms, KFD is more common in young Asian women, with a peak age of onset between 25 and 29 years and a male-to-female ratio of 1:3-1:4 (3). In demographic terms, the distribution of KFD with meningitis has its own particular characteristics. Among the 41 cases of KFD with aseptic meningitis identified worldwide (Table 2), the ethnic origins of the patients were European (5\%), North American (7\%), African (2\%), and Asian (86\%). Japan had the highest prevalence worldwide, accounting for $41 \%$ of cases. The average patient age was 22 years ( $80 \%$ of the patients were $<30$ years old), and the sex (male/female) ratio was 1.28:1.

Commonly, fever and regional lymphadenopathy are the main clinical manifestations of KFD. In addition, KFD can cause uveitis, subretinal macular infiltration, acute renal failure, hemophagocytosis syndrome, interstitial pulmonary disease, and other rare complications (32). About $60-90 \%$ of patients present with long-term fever of unknown cause and temperature fluctuations ranging from 38 to $41^{\circ} \mathrm{C}$. Posterior cervical lymphadenopathy is often the initial symptom, which is usually unilateral, accounting for $88.5 \%$ of cases (3). Up to $40 \%$ of patients with KFD may present with non-specific rashes, which may appear on the scalp, face, chest, back, and limbs, presenting with urticaria, rubella, erythema multiforme, papules, and papular abscesses (33). Our patient had a persistent fever after admission, with the highest temperature being $38.1^{\circ} \mathrm{C}$. Several days after admission, the patient developed a skin rash and cervical lymphadenopathy, both of which suggested KFD. On the other hand, our patient developed delayed lymphadenopathy, an uncommon finding in KFD that complicates the diagnosis of KFD.

The clinical manifestations of KFD involving the CNS are complex and diverse, including meningitis, encephalitis, subdural effusion, optic neuritis, cerebellar ataxia, hemiplegia, and other signs $(10,23,34-38)$. KFD concomitant with neurological symptoms is rare and prone to missed diagnosis and misdiagnosis. Aseptic meningitis is the most common CNS complication of KFD, accounting for $2.8-9.8 \%$ of KFD patients (39), mainly manifesting as headache, vomiting, and convulsion. Meningitis usually occurs 2-3 weeks after lymphadenopathy, while meningitis as a first symptom of KFD is rare (26). The course of KFD with aseptic meningitis usually takes 2-3 weeks, but a duration of 2-4 months has also been reported (26). A meta-analysis of 244 patients with KFD showed that 4.5\% (11 cases) were associated with neurological impairment, including aseptic meningitis (eight cases), polyneuritis, or acute cerebellar ataxia (40). To date, of the 41 KFD patients with aseptic meningitis reported globally (Table 2 ), $88 \%$ suffered headaches, 
TABLE 2 | The clinical features of recurrent aseptic meningitis cases with Kikuchi-Fujimoto disease.

\begin{tabular}{|c|c|c|c|c|c|c|c|c|c|c|c|c|c|c|c|c|}
\hline \multirow[t]{2}{*}{ Date/country } & \multirow{2}{*}{$\begin{array}{c}\text { Gender/ } \\
\text { age }\end{array}$} & \multirow{2}{*}{$\begin{array}{l}\text { Interval* } \\
\text { (weeks) }\end{array}$} & \multicolumn{5}{|c|}{ CNS clinical manifestations } & \multirow{2}{*}{$\begin{array}{c}\text { CNS } \\
\text { duration } \\
\text { (weeks) }\end{array}$} & \multicolumn{4}{|c|}{ CSF } & \multirow{2}{*}{$\begin{array}{c}\text { Head CT or } \\
\text { MRI } \\
\text { abnormality }\end{array}$} & \multirow{2}{*}{$\begin{array}{l}\text { Steroids } \\
\text { therapy }\end{array}$} & \multirow[t]{2}{*}{ Outcome } & \multirow[t]{2}{*}{ References } \\
\hline & & & Headache & Confusion & Convulsions & $\begin{array}{c}\text { Neck } \\
\text { stiffness }\end{array}$ & $\begin{array}{l}\text { Kernig's } \\
\text { signs }\end{array}$ & & $\begin{array}{l}\text { Pressure } \\
\left(\mathrm{mmH}_{2} \mathrm{O}\right)\end{array}$ & $\begin{array}{c}\text { WBC (x } \\
\left.10^{6} / \text { L }\right)\end{array}$ & $\begin{array}{l}\text { Protein } \\
\text { (mg/dl) }\end{array}$ & $\begin{array}{l}\text { Glucose } \\
\text { (mg/dl) }\end{array}$ & & & & \\
\hline 2020/China & $\mathrm{M} / 18$ & ND & + & + & - & - & - & 1 & 300 & $454 \mathrm{MC}$ & 400.1 & Nor & + & + & C & (4) \\
\hline 2020/Kenya & $F / 29$ & $\#$ & + & - & - & + & + & 3 & ND & $295^{\llcorner}$ & 56 & Nor & - & + & $\mathrm{R} \& \mathrm{C}$ & (5) \\
\hline 2019/India & $\mathrm{F} / 57$ & ND & + & - & - & - & - & 3 & ND & $30^{L}$ & 80.47 & 66 & + & + & C & (6) \\
\hline 2018/South Korea & $\mathrm{M} / 12$ & 3 & + & - & + & + & + & 2 & ND & $194^{L}$ & 312 & 52 & + & + & C & (7) \\
\hline 2018/South Korea & $\mathrm{M} / 17$ & 2 & + & - & - & - & - & 1 & ND & $163^{L}$ & 333 & $\mathrm{D}$ & + & + & C & (7) \\
\hline 2018/South Korea & $F / 15$ & 1 & - & + & - & - & - & ND & ND & $87^{\llcorner}$ & 116 & Nor & - & + & C & (7) \\
\hline 2018/India & $\mathrm{F} / 20$ & 0.5 & - & + & - & + & - & 4 & ND & $\mathbf{I}^{\mathrm{N}}$ & 299 & 69 & ND & + & C & (8) \\
\hline 2018/China & $\mathrm{M} / 20$ & $\#$ & + & - & - & + & + & 4 & 400 & $56^{\mathrm{MC}}$ & 56 & 63 & - & + & C & $\begin{array}{l}\text { Present case } \\
\text { (2018) }\end{array}$ \\
\hline 2018/India & $\mathrm{M} / 6$ & ND & + & - & - & - & - & 12 & ND & $160 \mathrm{MC}$ & I & D & - & + & C & (9) \\
\hline 2017/Japan & $\mathrm{M} / 19$ & ND & + & - & - & - & - & ND & ND & $24^{\mathrm{ND}}$ & 50 & Nor & + & + & C & (10) \\
\hline 2017/America & $F / 19$ & 1 & + & - & - & - & - & ND & 25.5 & $8^{\mathrm{L}}$ & Nor & Nor & ND & - & C & (11) \\
\hline 2016/India & $F / 15$ & 2 & - & + & - & + & + & 4 & ND & $45^{\llcorner}$ & 28 & 76 & + & + & C & (12) \\
\hline 2014/America & M/32 & ND & + & - & - & + & + & ND & ND & $14^{\mathrm{L}}$ & 63 & 82 & + & + & C & (13) \\
\hline 2014/America & $\mathrm{M} / 9$ & 3 & - & + & - & + & + & 2 & $>45$ & $I^{\llcorner}$ & 77 & ND & + & + & C & (14) \\
\hline 2013/China & $F / 25$ & ND & + & - & - & + & + & 4 & 215 & $199^{L}$ & 126 & 46 & - & + & $\mathrm{R} \& \mathrm{C}$ & (15) \\
\hline 2013/South Korea & $\mathrm{M} / 28$ & ND & + & - & - & + & - & 6 & 300 & $318^{\mathrm{L}}$ & 285 & 60 & - & + & C & (16) \\
\hline 2012/Japan & M/39 & 22 years & + & - & - & - & - & 8 & ND & $33^{L}$ & 167 & 54 & + & - & C & (17) \\
\hline 2012/Japan & $\mathrm{M} / 28$ & ND & + & - & - & - & + & 2 & ND & $27^{\mathrm{MC}}$ & 31 & 1 & ND & - & $\mathrm{R} \& \mathrm{C}$ & (18) \\
\hline 2011/Bangladesh & $F / 11$ & ND & + & + & - & - & - & 2 & ND & $30^{\mathrm{L}}$ & 89.7 & 42 & - & + & C & (15) \\
\hline 2010/Japan & $F / 35$ & ND & + & - & - & + & + & ND & 160 & $59^{\mathrm{MC}}$ & 148 & 80 & ND & + & $\mathrm{R} \& \mathrm{C}$ & (19) \\
\hline 2010/Turkey & F/36 & 7 & + & - & + & - & - & 12 & ND & $40^{N}$ & 61 & 49 & + & + & C & (20) \\
\hline 2009/South Korea & $F / 13$ & 4 & + & - & - & - & - & $N D$ & 180 & $65^{\llcorner}$ & 28 & 56 & $N D$ & - & C & (21) \\
\hline 2008/Japan & $\mathrm{M} / 29$ & ND & + & - & - & - & - & 4 & ND & 63 ND & ND & ND & ND & + & $\mathrm{R} \& \mathrm{C}$ & (22) \\
\hline 2007/China & $\mathrm{M} / 25$ & $\#$ & + & - & - & - & - & 4 & 260 & $15^{\mathrm{ND}}$ & 128 & 48 & - & + & C & (21) \\
\hline 2005/Britain & $F / 37$ & $1 / 3$ & + & - & - & + & - & 1 & 200 & $30^{\mathrm{MC}}$ & 71 & Nor & - & + & C & (23) \\
\hline 2005/South Korea & $\mathrm{M} / 23$ & $\#$ & + & - & - & - & - & 16 & 300 & $283^{\mathrm{MC}}$ & 86 & 44 & - & - & C & (24) \\
\hline 2003/India & $F / 17$ & ND & + & - & + & - & - & ND & ND & ND & I & ND & - & - & C & (25) \\
\hline 1999/Japan & $\mathrm{M} / 27$ & 6 & + & - & - & - & - & 5 & 200 & $78^{\mathrm{L}}$ & 58 & 46 & - & - & C & (26) \\
\hline 1999/Spain & $\mathrm{M} / 14$ & 3 & + & + & - & - & - & 12 & ND & $32^{\mathrm{MC}}$ & 48 & 68 & ND & + & C & (27) \\
\hline 1998/India & $F / 12$ & ND & + & - & - & - & + & ND & ND & $100^{N D}$ & ND & ND & - & + & $\mathrm{R} \& \mathrm{C}$ & (28) \\
\hline 1996/Japan & $\mathrm{M} / 48$ & 1 & - & + & - & - & - & 3 & ND & $135^{\llcorner}$ & 268 & 44 & ND & - & C & (29) \\
\hline 1992/Japan & $\mathrm{M} / 30$ & 3 & + & - & - & + & - & 5 & 190 & $124^{\mathrm{MC}}$ & 33 & 55 & / & - & C & (26) \\
\hline 1990/Japan & $\mathrm{F} / 21$ & 3 & + & - & - & - & - & 3 & 150 & $109^{M C}$ & 42 & 61 & / & - & C & (26) \\
\hline
\end{tabular}




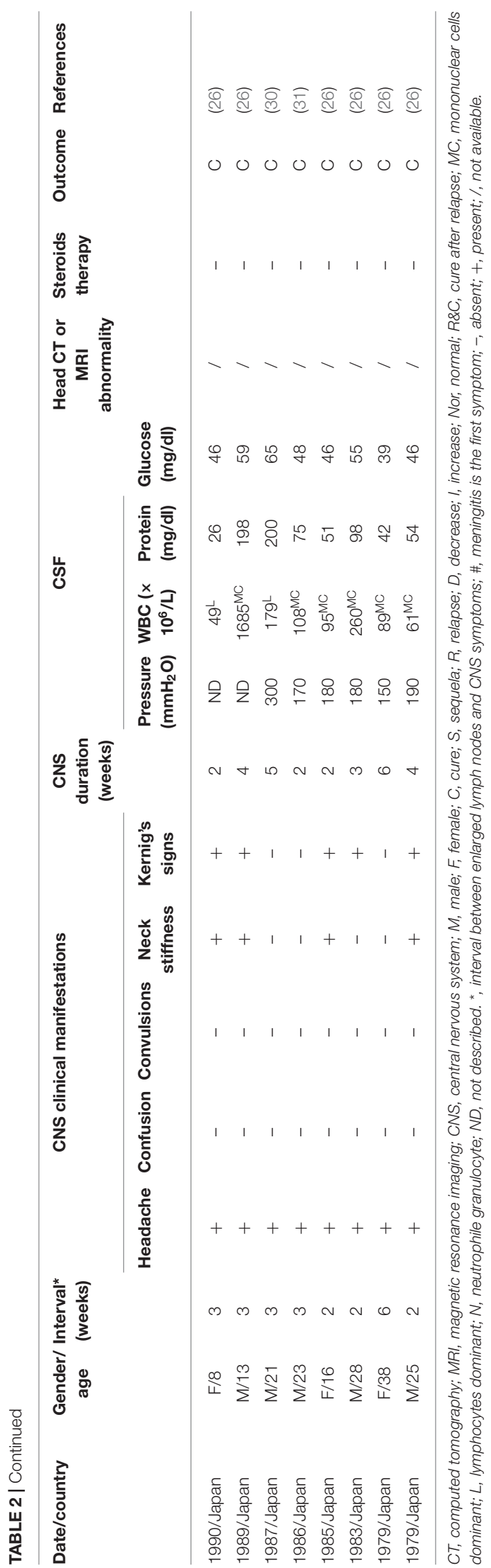

$19 \%$ had consciousness disorders, $7 \%$ had convulsions, $43 \%$ had neck stiffness, and $37 \%$ had positive Kernig's sign. As can be observed from Table 2, the average duration of CNS symptoms is 2-4 weeks, the longest is 4 months, and the shortest is 1 week. Among 41 patients with KFD with aseptic meningitis, 39 developed meningitis during the course of established KFD, while meningitis preceded other manifestations of KFD in only four patients. Moreover, the interval between lymphadenopathy onset and CNS symptoms was usually $1-3$ weeks.

There is a lack of specific laboratory and imaging examinations for KFD diagnosis. CSF examination in patients with KFD concurrent with aseptic meningitis is sterile, with normal or slightly raised ICP, CSF protein, and leukocytes (26). In the literature review (Table 2), nine patients showed increased CSF pressure $\left(200-400 \mathrm{~mm} \mathrm{H}_{2} \mathrm{O}\right)$, and the CSF pressure in one case was only $25.5 \mathrm{mmH}_{2} \mathrm{O}$. Only nine $\mathrm{KFD}$ patients with aseptic meningitis had increased ICP, which may be related to the vasogenic cerebral edema caused by the increased permeability of cerebral capillary endothelial cells. CSF leukocytes were elevated (in most patients, these ranged from 8 to $300 \times 10^{6} / \mathrm{L}$, and one patient had 1,685 $\times 10^{6} / \mathrm{L}$ CSF leukocytes), with predominant mononuclear lymphocytes (86\%). Furthermore, CSF protein was elevated $(50-400 \mathrm{mg} / \mathrm{dl})$ in $75 \%$ of patients, and the CSF glucose and chloride levels were mostly within the normal range. In patients with meningitis, irregular meningeal gadolinium enhancement and subdural effusion can be observed in enhanced magnetic resonance imaging (7). Among the 41 cases of KFD concurrent with aseptic meningitis (Table 2), 27\% had imaging abnormalities. Although laboratory and imaging results have little significance as diagnostic criteria for KFD, they can still be used for differential diagnosis to exclude other diseases.

The definitive diagnosis mainly depends on excisional biopsy and histopathological and immunohistochemical examination. Therefore, in the absence of lymph node biopsy, KFD is easily misdiagnosed as tuberculosis, lymphoma, or connective tissue disease. The pathological changes associated with KFD are dynamic, and Kuo divided KFD into three types according to disease progression: proliferative, necrotic, and xanthomatoid (41). Lymph node biopsy showed pathologically disrupted lymphoid structures, histiocyte proliferation, and nuclear debris $(42,43)$. The typical immunohistochemistry findings of this disease are myeloperoxidase ${ }^{+}$and $\mathrm{CD} 68^{+}$histiocytes $(44,45)$.

KFD is a benign, self-limiting disease, and most patients do not need special treatment (3). Moreover, it has a low recurrence rate ( 3 to $4 \%$ ), and only several fatal cases have been reported $(3,5,18)$. In the retrospective analysis of 11 cases (Table 2: cases 28 and 32-41) of KFD patients with meningitis, Sato et al. found that meningitis symptoms would spontaneously recede within 2-6 weeks without special treatment (26). As can be observed in Table 2, among the 41 cases of KFD with aseptic meningitis, 17 resolved spontaneously without steroid treatment, and six patients experienced a recurrence. Although there is no specific treatment for KFD, steroids may be used for patients with severe symptoms or with neurological lesions (23). Among all cases of KFD with aseptic meningitis (Table 2), 24 patients received steroid therapy, and 79\% of them fully recovered. 
Approximately 13-25\% of KFD cases have been associated with SLE (40, 46). Many reports even refer to KFD as an early stage of SLE (3). However, the relationship between the two diseases remains unclear, and the concept of KFD being an atypical manifestation of SLE is still controversial (47). Considering this association, we recommend following KFD patients over time.

This case report has several limitations. On one hand, a definite diagnosis of KFD mainly depends on excisional biopsy, which is an invasive examination. On the other hand, due to the short follow-up time, we cannot predict whether the patient will relapse or develop SLE in the future. Therefore, long-term follow-up of patients with KFD is warranted. In addition, the pathogenesis of KFD-associated meningitis remains challenging for clinicians, thus deserving further study.

\section{CONCLUSIONS}

Based on our observations, in patients with aseptic meningitis as the first symptom accompanied by cervical lymphadenopathy and rash, physicians should consider the diagnosis of KFD and perform lymph node biopsy at an early stage to avoid misdiagnosis and missed diagnosis and better guide the treatment. In addition, long-term follow-up should be performed in KFD patients with aseptic meningitis to monitor disease recurrence or progression to SLE.

\section{DATA AVAILABILITY STATEMENT}

The original contributions presented in the study are included in the article/supplementary material, further inquiries can be directed to the corresponding author/s.

\section{REFERENCES}

1. Kikuchi M. Lymphadenitis showing focal reticulum cell hyperplasia with nuclear debris and phagocytes: a clinicopathological study. Acta Hematol Jpn. (1972) 35:379-80.

2. Fujimoto Y, Kozima T, Yamaguchi K. Cervical subacute necrotizing lymphadenitis: a new clinicopathological entity. Naika. (1972) 20:920-7.

3. Bosch X, Guilabert A, Miquel R, Campo E. Enigmatic KikuchiFujimoto disease: a comprehensive review. Am J Clin Pathol. (2004) 122:141-52. doi: 10.1309/YF081L4TKYWVYVPQ

4. Huang X, Chen X, Tong SW, Wang Y, Cai J, Deng C, et al. KikuchiFujimoto disease complicated by aseptic meningitis and hemophagocytosis successfully treated with intrathecal dexamethasone. Heliyon. (2020) 6:e04193. doi: 10.1016/j.heliyon.2020.e04193

5. Sharma K, Otieno F, Shah R. Case report of kikuchi-fujimoto disease from sub-saharan africa: an important mimic of tuberculous lymphadenitis. Case Rep Med. (2020) 2020:4385286. doi: 10.1155/2020/43 85286

6. Patel DR, Shah AB, Shah HR, Thorat KB. Kikuchi disease: a rare cause of aseptic meningitis. Neurology India. (2019) 67:1131-3. doi: 10.4103/0028-3886.266242

7. Byun JH, Park SE, Nam SO, Kim YA, Kim YM, Yeon GM, et al. Three children of meningoencephalitis with Kikuchi necrotizing lymphadenitis. Brain Dev. (2018) 40:251-5. doi: 10.1016/j.braindev.2017.09.009

8. Jain J, Banait S, Tiewsoh I, Choudhari M. Kikuchi's disease (histiocytic necrotizing lymphadenitis): a rare presentation with acute kidney injury,

\section{ETHICS STATEMENT}

The studies involving human participants were reviewed and approved by the Ethics Committee of The First Hospital of Jilin University, China. The patients/participants provided their written informed consent to participate in this study. Written informed consent was obtained from the individual(s) for the publication of any potentially identifiable images or data included in this article.

\section{AUTHOR CONTRIBUTIONS}

YS conceived the idea, revised all the literature, and wrote the manuscript. SL and LSo collected the clinical data. HC, MB, JY, TL, KL, and LSu made tables and figures. YZ contributed to the revision of the manuscript and read and approved the submitted version. All authors have read and approved the final manuscript.

\section{FUNDING}

This study was supported by the National Natural Science Foundation of China (Grant No. 81600924 for YZ and Grant No. 81701293 for TL) and the National Key Research and Development Project of China (Grant No. 2018YFC1312301 for LSu).

\section{ACKNOWLEDGMENTS}

We thank the patient and the families for their participation in this study.

peripheral neuropathy, and aseptic meningitis with cutaneous involvement. Indian J Pathol Microbiol. (2018) 61:113-5.doi: 10.4103/IJPM.IJPM_256_17

9. Deepa CM, Rao AP. Kikuchi-fujimoto disease (histiocytic necrotizing lymphadenitis) associated with aseptic meningitis. Indian J Rheum. (2018) 13:71-2. doi: 10.4103/injr.injr_119_17

10. Kido H, Kano O, Hamai A, Masuda H, Fuchinoue Y, Nemoto M, et al. Kikuchi-Fujimoto disease (histiocytic necrotizing lymphadenitis) with atypical encephalitis and painful testitis: a case report. BMC Neurol. (2017) 17:22. doi: 10.1186/s12883-017-0807-4

11. Trivedi ND, Parsons AS. Kikuchi-Fujimoto disease: an unusual presentation of meningitis in a returning traveller. BMJ Case Rep. (2017) 2017:221422. doi: 10.1136/bcr-2017-221422

12. Jasti DB, Naveen Prasad SV, Naveen T, Vengamma B. Kikuchi-Fujimoto disease presenting as brainstem encephalitis with secondary blepharospasm. J Neurosci Rural Pract. (2016) 7:157-60. doi: 10.4103/0976-3147. 165395

13. Khishfe BF, Krass LM, Nordquist EK. Kikuchi disease presenting with aseptic meningitis. Am J Emerg Med. (2014) 32:1298.e12. doi: 10.1016/j.ajem.2014.03.029

14. Gonçalves LF, Debelenko LV, Bhambhani KJ, Scheid A, Altinok D. Histiocytic necrotizing lymphadenitis (Kikuchi-Fujimoto disease) with CNS involvement in a child. Pediatr Radiol. (2014) 44:234-8. doi: 10.1007/s00247-013-2786-y

15. Yaqing S, Wei Q, Xueping Z, Zhengqi L, Jianning C, Xueqiang H. KikuchiFujimoto's disease with meningitis and abnormal serum immune phenomena: a case report and review. Chin J Neurol. (2013) 46:592-6. doi: 10.3760/cma.j.issn.1006-7876.2013.09.004 
16. Choi YJ, Lee SH, Lee JK, Nam TS, Choi SM, Kim BC, et al. Aseptic meningitis in Kikuchi's disease mimicking tuberculous meningitis. Neurol Sci. (2013) 34:1481-3. doi: 10.1007/s10072-012-1230-7

17. Guéguen A, Sené T, Maillart E, Gout O. Encephalitis and CSF increased level of interferon- $\alpha$ in Kikuchi-Fujimoto disease. BMJ Case Rep. (2012) 2012:5579. doi: 10.1136/bcr.01.2012.5579

18. Komagamine T, Nagashima T, Kojima M, Kokubun N, Nakamura T, Hashimoto K, et al. Recurrent aseptic meningitis in association with KikuchiFujimoto disease: case report and literature review. BMC Neurol. (2012) 12:112. doi: 10.1186/1471-2377-12-112

19. Yamashita T, Shibata K, Nagano S, Aishima S, Yoshimura T. [A case of subacute necrotizing lymphadenitis with recurrent aseptic meningitis associated with persistent high titer of anti-nuclear antibody occurring over a short period of time]. Rinsho Shinkeigaku. (2010) 50:72831. doi: 10.5692/clinicalneurol.50.728

20. Avkan-Oguz V, Yapar N, Ozakbas S, Demir-Onder K, Aktas E, Alp-Cavus S, et al. A case of fever of unknown origin: co-existence of Kikuchi-Fujimoto disease and acute disseminated encephalomyelitis (ADEM). Intern Med. (2010) 49:1823-6. doi: 10.2169/internalmedicine.49.3633

21. Xin G, Heying C, Shaoying L, Huili H, Tianming C, Gang L. Histiocytic necrotizing lymphadenitis combined with central nervous system damage in 4 children. Chin J Appl Clin Pediatrics. (2016) 31:683-6. doi: 10.3760/cma.j.issn.2095-428X.2016.09.011

22. Itokawa K, Fukui M, Nakazato Y, Yamamoto T, Tamura N, Sannohe S, et al. [A case of subacute necrotizing lymphadenitis with recurrent aseptic meningitis 11 years after the first episode]. Rinsho Shinkeigaku. (2008) 48:2757. doi: $10.5692 /$ clinicalneurol.48.275

23. Noursadeghi M, Aqel N, Pasvol G. Kikuchi's disease: a rare cause of meningitis? Clin Infect Dis. (2005) 41:e80-2. doi: 10.1086/444563

24. Yang HD, Lee SI, Son IH, Suk SH. Aseptic meningitis in kikuchi's disease. J Clin Neurol. (2005) 1:104-6. doi: 10.3988/jen.2005.1.1.104

25. Soman R, Ashar U, Shukla A, Pachauri R, Bhaduri A. Kikuchi Fujimoto disease with unusual features. J Assoc Physicians India. (2003) 51:314-5.

26. Sato $\mathrm{Y}$, Kuno H, Oizumi K. Histiocytic necrotizing lymphadenitis (Kikuchi's disease) with aseptic meningitis. J Neurol Sci. (1999) 163:187-91. doi: 10.1016/S0022-510X(99)00037-4

27. Sierra ML, Vegas E, Blanco-González JE, GonzálezA, Martínez P, Calero MA. Kikuchi's disease with multisystemic involvement and adverse reaction to drugs. Pediatrics. (1999) 104:e24. doi: 10.1542/peds.104.2.e24

28. Mathew LG, Cherian T, Srivastava VM, Raghupathy P. Histiocytic necrotizing lymphadenitis (Kikuchi's disease) with aseptic meningitis. Indian Pediatr. (1998) 35:775-7.

29. Atarashi K, Yoshimura N, Nodera H, Tsukimoto K, Beppu H, Kanayama M. Recurrent histiocytic necrotizing lymphadenitis (Kikuchi's disease) in an human T lymphotropic virus type I carrier. Intern Med. (1996) 35:8215. doi: 10.2169/internalmedicine.35.821

30. Maeda T, Ashie T, Ishiyama N, Kikuiri K, Mori Y, Shimamoto K, et al. [A case of necrotizing lymphadenitis associated with aseptic meningitis]. Nihon Naika Gakkai Zasshi. (1987) 76:1073-7. doi: 10.2169/naika.76.1073

31. Yamasaki Y, Chiba S, Misago M, Tsuda T, Oda S, Oda E, et al. [A case of subacute necrotizing lymphadenitis associated with aseptic meningitis]. Nihon Naika Gakkai Zasshi. (1986) 75:687-90. doi: 10.2169/naika.75.687

32. Kapoor S. Rare complications of kikuchi's disease: beyond pain control. Kor J Pain. (2012) 25:281-2. doi: 10.3344/kjp.2012.25.4.281

33. Gaman M, Vladareanu AM, Dobrea C, Onisai M, Marinescu C, Voican I, et al. A challenging case of kikuchi-fujimoto disease associated with systemic lupus erythematosus and review of the literature. Case Rep Hematol. (2018) 2018:1791627. doi: 10.1155/2018/1791627
34. Shahid S, Alam SH, Hadley I. An unusual presentation of kikuchifujimoto disease with recurrent subdural effusion. Cureus. (2018) 10:e2302. doi: 10.7759/cureus.2302

35. Ciampi E. Optic neuritis revealing Kikuchi-Fujimoto's disease: clinical commentary. Multiple Scler. (2014) 20:11434. doi: 10.1177/1352458514526441

36. Moon JS, Il Kim G, Koo YH, Kim HS, Kim WC, Kim OJ, et al. Kinetic tremor and cerebellar ataxia as initial manifestations of Kikuchi-Fujimoto's disease. $J$ Neurol Sci. (2009) 277:181-3. doi: 10.1016/j.jns.2008.10.021

37. Liu L, Tan X, Liu Y, Liu Z, Yang J, Huang Q. Kikuchi disease as a possible cause of ischaemic stroke: a case report. Int J Neurosci. (2020) 499:13. doi: 10.1080/00207454.2020.1763341

38. Shabana M, Warnack W. An atypical neurologic complication of Kikuchi-Fujimoto disease. Neurology(R) Neuroimmun Neuroinfl. (2020) 7:707. doi: 10.1212/NXI.0000000000000707

39. Nakamura I, Imamura A, Yanagisawa N, Suganuma A, Ajisawa A. [Medical study of 69 cases diagnosed as Kikuchi's disease]. Kansenshogaku zasshi J Japanese Assoc Infect Dis. (2009) 83:3638. doi: 10.11150/kansenshogakuzasshi.83.363

40. Kucukardali Y, Solmazgul E, Kunter E, Oncul O, Yildirim S, Kaplan M. Kikuchi-Fujimoto Disease: analysis of 244 cases. Clin Rheumatol. (2007) 26:50-4. doi: 10.1007/s10067-006-0230-5

41. Kuo TT. Kikuchi's disease (histiocytic necrotizing lymphadenitis). A clinicopathologic study of 79 cases with an analysis of histologic subtypes, immunohistology, and DNA ploidy. Am J Surg Pathol. (1995) 19:798809. doi: 10.1097/00000478-199507000-00008

42. Seong GM, Kim JH, Lim GC, Kim J. Clinicopathological review of immunohistochemically defined Kikuchi-Fujimoto disease-including some interesting cases. Clin Rheumatol. (2012) 31:1463-9. doi: 10.1007/s10067-012-2036-y

43. Hutchinson CB, Wang E. Kikuchi-Fujimoto disease. Arch Pathol Lab Med. (2010) 134:289-93. doi: 10.5858/134.2.289

44. Bogusz AM, Bhargava P. Recurrent histiocytic necrotizing lymphadenitis with a long latency in a patient with autoimmunity: a case report and review of literature. Int J Surg Pathol. (2013) 21:287-96. doi: 10.1177/10668969124 67369

45. Fiorella ML, Gelardi M, Marzullo A, Sabattini E, Fiorella R. Kikuchi-Fujimoto disease: an uncommon cause of neck swelling. Europ Arch Oto-Rhino-Laryng. (2017) 274:1761-4. doi: 10.1007/s00405-016-4147-6

46. Dumas G, Prendki V, Haroche J, Amoura Z, Cacoub P, Galicier $\mathrm{L}$, et al. Kikuchi-Fujimoto disease: retrospective study of 91 cases and review of the literature. Medicine (Baltimore). (2014) 93:372-82. doi: 10.1097/MD.0000000000000220

47. Baenas DF, Diehl FA, Haye Salinas MJ, Riva V, Diller A, Lemos PA. KikuchiFujimoto disease and systemic lupus erythematosus. Int Med Case Rep J. (2016) 9:163-7. doi: 10.2147/IMCRJ.S106396

Conflict of Interest: The authors declare that the research was conducted in the absence of any commercial or financial relationships that could be construed as a potential conflict of interest.

Copyright (C) 2021 Song, Liu, Song, Chen, Bai, Yan, Luo, Liu, Sun and Zhao. This is an open-access article distributed under the terms of the Creative Commons Attribution License (CC BY). The use, distribution or reproduction in other forums is permitted, provided the original author(s) and the copyright owner(s) are credited and that the original publication in this journal is cited, in accordance with accepted academic practice. No use, distribution or reproduction is permitted which does not comply with these terms. 